\title{
Pengaruh Model Pembelajaran Learning Cycle 7E Terhadap Hasil Belajar Fisika Siswa SMA
}

\author{
Izzah Imaniyah $^{\text {a) }}$, Siswoyo ${ }^{\text {b) }}$, Fauzi Bakric) $^{\text {( ) }}$ \\ Program Studi Pendidikan Fisika, Fakultas MIPA, Universitas Negeri Jakarta, Jakarta 13220

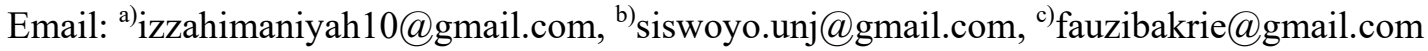

\begin{abstract}
This research aimed to know the effect of Learning Cycle 7E towards student's study result. The research is conducted in the 107 Senior High School Jakarta. The subjects are students of 11th grade of Science 2 as experiment class (Learning Cycle 7E) and Science 3 as control class (5M Cycle). The research is about Dynamic Fluid concept. The method and design are Quasi Experimental and Nonequivalent Control Group Design. The instrument of study result is multiple choice in cognitive area. The result of normality test by Chi Square showed distributions of data is normal. The result of homogenity test by F-test showed the class is homogen. Hyphothesis test used t-test with $\alpha=0,05$ and $\mathrm{dk}=65$. The result are tvalue $=4,994$ and ttable $=1,671$, so tvalue $>$ ttable, so there is positive effect of Learning Cycle 7E toward study result of 11 th grade.
\end{abstract}

Keywords: learning model, learning cycle 7E, study result

\begin{abstract}
Abstrak
Penelitian ini bertujuan untuk mengetahui pengaruh model pembelajaran Learning Cycle $7 E$ terhadap hasil belajar fisika. Sampel dari penelitian ini adalah siswa SMAN 107 Jakarta yaitu XI MIPA 2 sebagai kelas eksperimen (Learning Cycle 7E) dan kelas XI MIPA 3 sebagai kelas kontrol (siklus 5M). Penelitian dilakukan dalam pembelajaran konsep Fluida Dinamis. Metode dan desain yang digunakan adalah quasi eksperimen dan Nonequivalent Control Group Design. Instrumen hasil belajar berupa tes pilihan ganda dalam ranah kognitif yang telah diuji validitas dan reabilitasnya. Hasil perhitungan normalitas data dengan menggunakan Chi Kuadrat diperoleh data kedua kelompok terdistribusi normal. Hasil perhitungan homogenitas dengan menggunakan uji $\mathrm{F}$ diperoleh data kedua kelompok homogen. Uji hipotesis menggunakan uji t dengan taraf signifikansi $\alpha=0,05 \mathrm{dan} \mathrm{dk}=65$. Dari hasil perhitungan diperoleh $t_{\text {hitung }}=4,994$ dan $t_{\text {tabel }}=1,671$, yang berarti bahwa $t_{\text {hitung }}>t_{\text {tabel }}$, sehingga diperoleh kesimpulan bahwa terdapat pengaruh positif penerapan model pembelajaran Learning Cycle $7 E$ terhadap hasil belajar siswa kelas XI SMA pada taraf signifikansi 5\%.
\end{abstract}

Kata-kata kunci: model pembelajaran, siklus belajar 7E, hasil belajar

\section{PENDAHULUAN}

Terdapat penelitian yang mengatakan bahwa motivasi belajar fisika siswa terdata masih rendah dalam penguasaan materi maupun proses belajarnya. Hal ini berdasarkan hasil penelitian Gede Bandem Samudra, I Wayan Susatra, dan Ketut Suma dalam e-Journal Program Pascasarjana Universitas Pendidikan Ganesha dengan artikel berjudul "Permasalahan-permasalahan yang Dihadapi 
Siswa SMA di Kota Singaraja dalam Mempelajari Fisika" tahun 2014, menyatakan bahwa permasalahan-permasalahan yang dihadapi siswa SMA di Singaraja dalam belajar fisika ada dua yaitu sulitnya memahami pelajaran fisika dan tidak sukanya siswa terhadap pelajaran fisika, kesulitan siswa dalam mempelajari fisika dibedakan oleh dua hal yaitu materi fisika yang padat, menghapal, dan menghitung, serta pembelajaran fisika di kelas yang tidak kontekstual, tidak sukanya siswa terhadap pelajaran fisika disebabkan karena pada pembelajaran fisika di kelas guru tidak memperhatikan siswa.

Tidak hanya motivasi belajar, hasil belajar fisika siswa juga terdata masih rendah. Berdasarkan hasil survei PISA 2012 yang mengatakan bahwa Indonesia termasuk ke dalam peringkat ke 64 dari 65 negara baik untuk bidang matematika maupun bidang sains. Survei PISA dilakukan terhadap siswa Indonesia yang berumur 15 tahun, yang berarti setara dengan tingkat SMA karena fisika mengandung matematika dan sains di dalam materinya sehingga secara umum hasil survei PISA juga menggambarkan hasil belajar fisika. Siswa-siswa SMA yang disurvei PISA mempunyai pemahaman matematika (nilai rata-rata 375) maupun sains (nilai rata-rata 382) yang rendah dibandingkan ratarata 65 negara yang di survei (rata-rata PISA matematika 494 dan sains 501). Dilihat dari permasalahan tesebut, maka perlunya suatu model pembelajaran yang tepat yang melibatkan siswa secara aktif. Dilihat dari permasalahan tesebut, maka perlunya suatu model pembelajaran yang tepat.

Model siklus belajar bila diterapkan dalam pembelajaran akan meningkatkan prestasi dan pemahaman sains. Hal ini berdasarkan penelitian Brenda H. Spencer dan Andrea M. Guillaume dalam jurnal The Reading Teacher dengan artikel berjudul "Integrating curriculum through the learning cycle: Content-based reading and vocabulary instruction" mengatakan bahwa siklus belajar bila diterapakan akan meningkatkan prestasi sains (termasuk pengingatan konsep) dan meningkatkan sikap dan proses sciencetific serta berparuh positif terhadap pemahaman sains.

Salah satu model siklus belajar adalah model pembelajaran Learning Cycle 7E yang dapat mengurangi miskonsepsi fisika pada siswa. Hal ini setara dengan penelitian Selahattin Gonen (Professor dari Dicle University Turkey) dalam jurnal TOJDE dengan artikel berjudul "A physics lesson designed according to 7E model with the help of instructional technology (lesson plan)" mengatakan bahwa perlunya perencananaan pembelajaran dengan menyajikan materi dan bahan ajar dengan model pembelajaran Learning Cycle 7E untuk mengurangi miskonsepsi fisika pada siswa. Oleh karena itu jika dihubungkan dengan penelitian ini, dapat disintesiskan bahwa penggunaan model pembelajaran Learning Cycle 7E berpengaruh positif terhadap pemahaman konsep fisika siswa.

Model pembelajaran Learning Cycle 7E berpengaruh positif terhadap hasil belajar fisika siswa. Hal ini berdasarkan hasil penelitian Damar Septian dalam skripsi yang menggunakan metode quasi eksperimen yang berjudul "Pengaruh Model LC 7E dalam Pembelajaran Fisika terhadap Hasil Belajar Fisika Siswa MAN Rembang Tahun Ajaran 2010/2011", menyatakan bahwa penerapan model Learning Cycle 7E berpengaruh positif terhadap hasil belajar kognitif, afektif dan psikomotorik siswa.

Dalam proses pembelajaran fisika lebih menekankan pada keterampilan proses untuk menemukan teori dan konsep, dan hal ini mempengaruhi kualitas dalam pembelajaran. Seperti yang dikatakan Trianto (2014: 143) proses belajar mengajar IPA (fisika) lebih ditekankan pada pendekatan keterampilan proses, hingga siswa dapat menemukan fakta-fakta, membangun konsep-konsep, teoriteori dan sikap ilmiah siswa itu sendiri yang akhirnya dapat berpengaruh positif terhadap kualitas pendidikan maupun produk pendidikan.

Model siklus belajar adalah model pembelajaran yang berpusat pada siswa. Berdasarkan Yunita (2014: 43) mengatakan bahwa model pembelajaran sains berbasis kontruktivisme dan metode pengajarannya berpusat pada siswa adalah learning cycle (siklus belajar). Ada banyak macam model pembelajaran bersiklus, dalam kurikulum 2013 dikenalkan siklus pembelajaran 5M (Mengamati, Menanya, Mencoba, Mengasosiasi, dan Mengkomunikasikan), ada juga siklus belajar 5E dan siklus belajar 7E.

Model pembelajaran Learning Cycle 7E adalah model siklus belajar yang melibatkan siswa secara aktif melalui 7 fase dalam pembelajaran, yaitu elicit, engange, explore, explain, elaborate, evaluate, dan extend. Hal ini berdasarkan penelitian Arthur Eeisenkraft dalam jurnal The Science Teacher dengan artikel berjudul "Expanding the 5E Model" mengatakan bahwa model 7E mengembangkan 5 
tahapan dari model 5E menjadi 7 tahapan yaitu elicit, engange, explore, explain, elaborate, evaluate, dan extend. Seperti menurut Yunita (2014: 43-46) model pembelajaran Learning Cycle 7E adalah merupakan model siklus belajar yang melibatkan siswa secara aktif melalui 7 fase dalam pembelajaran. Elicit adalah fase mendatangkan pengetahuan awal siswa. Engange adalah ide, rencana pembelajaran dan pengalaman. Explore adalah fase yang membawa siswa untuk memperoleh pengetahuan dengan pengalaman langsung yang berhubungan dengan konsep yang akan dipelajari. Explain adalah fase yang berisi ajakan terhadap siswa untuk menjelaskan konsep-konsep dan definisi-definisi awal yang didapatkan ketika fase eksplorasi. Elaborate adalah fase yang bertujuan untuk membawa siswa menerapkan simbol-simbol, definisi-definisi, konsep-konsep, dan keterampilan-keterampilan pada permasalahan-permasalahan yang berkaitan dengan contoh dari pelajaran yang dipelajari. Evaluate adalah fase evaluasi dari hasil pembelajaran yang telah dialakukan. Extend adalah fase yang bertujuan untuk berfikir, mencari, menemukan dan menjelaskan contoh penerapan konsep yang telah dipelajari bahkan kegiatan ini dapat merangsang siswa untuk mencari hubungan konsep yang dipelajari dengan konsep lain yang sudah atau belum dipelajari.

Berangkat dari studi pendahuluan dari skripsi dan jurnal di atas, dan fakta-fakta yang ada maka dapat disimpulkan bahwa proses pembelajaran fisika yang menekankan pada keterampilan sains sangat sesuai dengan model pembelajaran Learning Cycle 7E. Dari inilah penulis bergerak untuk mengadakan penelitian dengan pertimbangan untuk menggali dan mengetahui pengaruh model pembelajaran Learning Cycle 7E terhadap hasil belajar siswa SMA dalam penelitian dengan judul "Pengaruh Model Pembelajaran Learning Cycle 7E terhadap Hasil Belajar Fisika Siswa".

\section{METODE PENELITIAN}

Metode penelitian yang dilakukan adalah metode quasi eksperimen. Pada penelitian ini diberikan perlakuan yang berbeda di dalam kelas, Untuk kelas eksperimen menggunakan model pembelajaran Learning Cycle 7E dan untuk kelas kontrol menggunakan kurikulum 2013 yaitu siklus 5M.

Desain penelitian menggunakan Nonequivalent Control Group Design. Dalam hal ini peneliti memberikan pretest ke 3 kelas MIPA di SMAN 107 Jakarta. Hasil pretest digunakan untuk mengetahui 2 kelas yang memiliki tingkat kemampuan yang sama yang nantinya akan diberikan perlakuan (treatment). Setelah diberikan treatment maka akan diberikan posttest untuk mengetahui hasil belajar siswa.

TABEL 1. Nonequivalent Control Design

\begin{tabular}{ccc}
\hline Pretest & Perlakuan & Posttest \\
\hline $\mathrm{O}_{1}$ & $\mathrm{X}$ & $\mathrm{O}_{2}$ \\
$\mathrm{O}_{1}$ & & $\mathrm{O}_{2}$ \\
\hline
\end{tabular}

\section{HASIL DAN PEMBAHASAN}

\section{Hasil Penelitian}

\section{1) Deskripsi Data}

Sebelum diberikan perlakuan diberikan pretest ke 3 kelas MIPA yang ada untuk menentukan 2 kelas yang homogen. Berikut ini pemaparan hasil pretest ketiga kelas:

TABEL 2. Data Statisistik Deskriptif Pretest Siswa

\begin{tabular}{cccc}
\hline Statistik & XI MIPA 1 & XI MIPA 2 & XI MIPA 3 \\
\hline Banyak Siswa (n) & 34 & 35 & 32 \\
Nilai Minimum & 5 & 15 & 5 \\
Nilai Maksimum & 45 & 50 & 40 \\
Rentang & 40 & 35 & 35 \\
Rata-rata & 25 & 30,428 & 20,938 \\
Standar Deviasi & 7,653 & 8,669 & 8,621 \\
Variansi & 58,564 & 75,146 & 74,323 \\
\hline
\end{tabular}


Setelah didapatkan data statistik, untuk menentukan 2 kelas yang homogen maka diuji dengan uji Fisher, sebelum diuji homogentitas, data tersebut harus diuji normalitasnya, yaitu dengan menggunakan uji Chi Kuadrat. Untuk data nilai pretest XI MIPA 1 didapat $\chi^{2}$ hitung $=$ 1,828 , XI MIPA 2 didapat $\chi^{2}$ hitung $=1,45$, dan XI MIPA 3 didapat $\chi^{2}$ hitung $=6,469$. Ketiga kelas tersebut memiliki nilai dk yang sama yaitu $\mathrm{dk}=\mathrm{k}-1=6-1=5$ dengan $\alpha=5 \%$, maka harga $\chi_{\text {tabel }}^{2}$ $=11,07$. Karena $\chi_{\text {hitung }}^{2}$ masing-masing lebih kecil dari $\chi 2$ tabel, maka data pretest dari ketiga kelas tersebut masing-masing terditribusi normal.

Setelah data tersebut berdistribusi normal, maka diuji tingkat homogenitas dengan menggunakan uji Fisher, untuk MIPA 1 dan MIPA 2 didapat $F_{\text {hitung }}=1,283<\mathrm{F}_{\text {tabel }}=1,74$, untuk MIPA 1 dan MIPA 3 didapat $\mathrm{F}_{\text {hitung }}=1,269<\mathrm{F}_{\text {tabel }}=1,79$, dan untuk MIPA 2 dan MIPA 3 didapat $\mathrm{F}_{\text {hitung }}=1,011<\mathrm{F}_{\text {tabel }}=1,74$. Dari hasil tersebut di dapat bahwa 3 pasangan kelas masing-masing $\mathrm{F}_{\text {hitung-nya }}<\mathrm{F}_{\text {tabel }}$ sehingga masing-masing homogen. Tetapi karena MIPA 2 dan MIPA 3 memiliki data variansi yang lebih sama sehingga $F_{\text {hitung-nya lebih kecil, maka }}$ lebih homogen sehingga di ambilah kelas XI MIPA 2 dan MIPA 3 sebagai kelas yang akan diberikan perlakuan. Dengan XI MIPA 2 sebagai kelas eksperimen dengan model pembelajaran Learning Cycle $7 E$ dan XI MIPA 3 sebagai kelas kontrol dengan siklus belajar $5 \mathrm{M}$.

Setelah diberikan perlakuan, kelas eksperimen dan kelas kontrol diberikan posttest untuk mengukur hasil belajarnya. Berikut hasil posttestnya:

TABEL 3. Data Statisistik Deskriptif Posttest Siswa Kelas Eksperimen dan Kelas Kontrol

\begin{tabular}{cccc}
\hline Statistik & XI MIPA 1 & XI MIPA 2 & XI MIPA 3 \\
\hline Banyak Siswa (n) & 34 & 35 & 32 \\
Nilai Minimum & 5 & 15 & 5 \\
Nilai Maksimum & 45 & 50 & 40 \\
Rentang & 40 & 35 & 35 \\
Rata-rata & 25 & 30,428 & 20,938 \\
Standar Deviasi & 7,653 & 8,669 & 8,621 \\
Variansi & 58,564 & 75,146 & 74,323 \\
\hline
\end{tabular}

Setelah mendapat hasil posttest, didapat bahwa pada kelas eksperimen terdapat sebanyak $62,857 \%$ siswa memperoleh nilai di atas rata-rata kelas, sedangkan 37, 143\% siswa memperoleh nilai di bawah rata-rata kelas. Pada kelas kontrol sebanyak 68,75\% siswa memperoleh nilai di atas rata-rata kelas, sedangkan 40,625\% siswa memperoleh nilai di bawah rata-rata kelas.

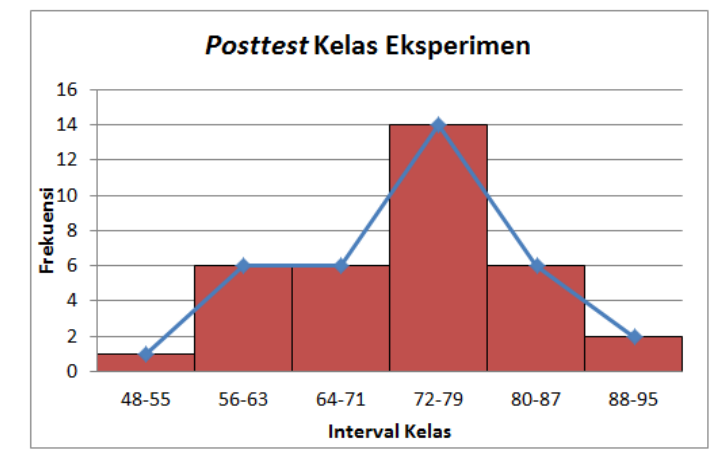

(a)

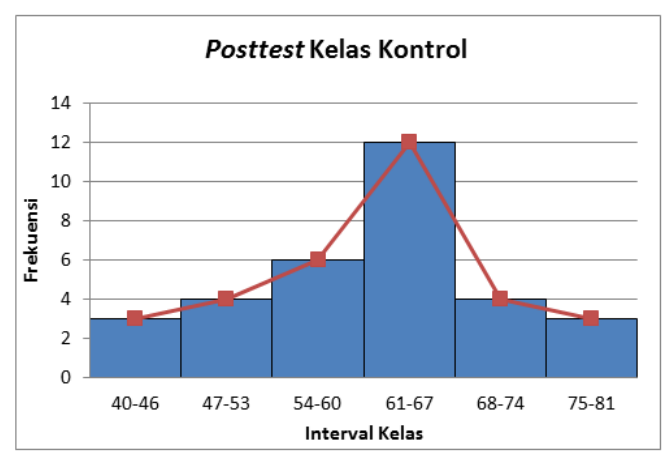

(b)

GAMBAR 1. (a) Histogram Hasil Belajar Fisika Siswa Kelas Eksperimen, (b) Histogram Hasil Belajar Fisika Siswa Kelas Kontrol 


\section{2) Pengujian Prasyarat Analisis}

a) Uji Normalitas

Uji normalitas dilakukan untuk mengetahui apakah data yang dieproleh berdistribusi normal atau tidak. Uji normalitas menggunakan uji Chi Kuadrat $\left(\chi^{2}\right)$ dengan data yang digunkan adalah hasil belajar siswa kelas eksperimen dan kelas kontrol. Hasil pengujian keals eksperimen diperoleh nilai $\chi^{2}$ hitung $=2,942$ dan kelas kontrol diperoleh nilai $\chi^{2}$ hitung $=$ 3,827 dengan $\mathrm{dk}=\mathrm{k}-1=6-1=5$ dan $\alpha=5 \%$ maka $\chi_{\text {tabel }}^{2}=11,07$. Berdasarkan data tersebut bahwa masing-masing kelas menunjukkan $\chi^{2}$ hitung $<\chi^{2}$ tabel sehingga kedua data tersebut terdistribusi normal.

b) Uji Homogenitas

Setelah kedua data terdistribusi normal, maka diuji tingkat kesamaan variansi atau uji homogenitas untuk mengetahui apakah kedua sampel homogen atau tidak. Uji homogenitas menggunkan uji Fisher dengan $\alpha=5 \%$ dengan dk pembilang $=\mathrm{n}-1=35-1=34 \mathrm{dan} \mathrm{dk}$ penyebut $=\mathrm{n}-1=32-1=3$. Hasil pengujian diperoleh $\mathrm{F}_{\text {hitung }}=1,012$ dan $\mathrm{F}_{\text {tabel }}=1,74$. Karena $F_{\text {hitung }}<F_{\text {tabel }}$, maka kedua data homogen.

c) Uji Hipotesis

Uji hipotesis digunakan untuk mengetahui apakah perlakuan yang diberikan berpengaruh terhadap hasil belajar siswa. Uji hipotesis ini menggunkan $t$-test uji beda dengan kedua data homogen dan $\mathrm{n}_{1} \neq \mathrm{n}_{2}$ yaitu $\mathrm{n}_{1}=35$ dan $\mathrm{n}_{2}=32$, sehingga menggunkan uji the pooled variance. Uji hipotesis dengan $\alpha=5 \%$ dan $\mathrm{dk}=\mathrm{n}_{1}+\mathrm{n}_{2}-2=35+32-2=65$ sehingga didapat $t_{\text {hitung }}=4,994$ dengan $\mathrm{t}_{\text {tabel }}=1,671$. Karena $\mathrm{t}_{\text {hitung }}>\mathrm{t}_{\text {tabel }}$, maka $\mathrm{H}_{0}$ ditolak dan $\mathrm{H}_{1}$ diterima.

Dengan demikina diperoleh bahwa terdapat sehingga terdapat pengaruh positif model pembelajran Learning Cycle $7 E$ terhadap hasil belajar siswa.

\section{Pembahasan}

Berdasarkan hasil pengujian hipotesis yang telah dilakukan, menujukkan bahwa hasil belajar kognitif fisika siswa yang diberi perlkuan dengan model pembelajaran Leraning Cycle $7 E$ lebih tinggi daripasa hasil belajar fisika siswa yang diberi perlakuan dengan siklus belajar 5M.

Sebelum dilakukan proses pembelajaran, peneliti sebelumnya menyusus instrumen pembelajran terlebih dahulu, adapun instumen yang digunakan adalah Rencana Pelaksanaan Pembelajran (RPP), Lembar Kegiatan Siswa (LKS) dan Handout serta menyusun soal untuk pretest dan posttest. Instumen yang digunakan adalah 20 soal kognitif pretest dan 25 soal kognitif posttest. Materi pokok dalam penelitian ini adalah tentang Fluida Dinamis.

Sebelum dilakukan proses pembelajaran, siswa diberikan pretest untuk mengambil 2 kelas yang homogen dari 3 kelas MIPA yang ada. Setelah dihitung dengan uji normalitas dan homogenitas uji Fisher didapat bahwa kelas XI MIPA 2 dan XI MIPA 3 memiliki tingkat kemampuan yang sama. Setelah itu ditentukan XI MIPA 2 sebagai kelas eksperimen dengan total siswa 36 orang dan XI MIPA 3 sebagai kelas kontrol dengan total siswa 36 orang.

Pada kelas eksperimen diberikan pembelajaran dengan menggunakan model pembelajaran Learning Cycle 7E yaitu Elicit, Engange, Explore, Explain, Elaborate, Evaluate dan Extend sedangkan utnuk kelas kontrol menggunakan siklus belajar 5M pada kurikulum 2013 yaitu Mengamati, Menanya, Mencoba, Mengelaborasi dan Mengkomunikasikan.

1) Pertemuan Pertama

Pada pertemuan pertama materi tentang Fluida Ideal dan Asas Kontinuitas. Kelas eksperimen dilaksanakan pada tanggal 17 Maret 2015 dengan jumlah siswa yang hadir adalah 36 orang. Untuk kelas kontrol dilaksanakan pada tanggal 6 Maret 2015 dengan jumlah siswa yang hadir 34 orang.

2) Pertemuan Kedua

Pada pertemuan pertama materi tentang Asas Bernoulli. Kelas eksperimen dan kelas kontrol dilaksanakan pada tanggal 19 Maret 2015. Untuk kelas eksperimen jumlah siswa yang hadir adalah 36 orang. Untuk kelas kontrol jumlah siswa yang hadir adalah 35 orang 


\section{3) Pertemuan Ketiga}

Pada pertemuan pertama materi tentang Tangki Berlubang. Kelas eksperimen dilaksanakan pada tanggal 24 Maret 2015 dengan jumlah siswa yang hadir adalah 34 orang sedangkan kelas kontrol dilaksanakan pada tanggal 20 Maret 2015 dengan jumlah siswa yang hadir adalah 36 orang.

4) Pertemuan Keempat

Pada pertemuan pertama materi tentang Venturimeter. Kelas eksperimen dilaksanakan pada tanggal 7 April 2015 dengan jumlah siswa yang hadir adalah 36 orang sedangkan kelas kontrol dilaksanakan pada tanggal 9 April 2015 dengan jumlah siswa yang hadir adalah 33 orang.

5) Pertemuan Kelima

Pada pertemuan pertama materi tentang Penyemprot Nyamuk dan Gaya Angkat Pesawat. Kelas eksperimen dilaksanakan pada tanggal 9 April 2015 dengan jumlah siswa yang hadir adalah 35 orang, sedangkan kelas kontrol dilaksanakan pada tanggal 16 April 2015 dengan jumlah siswa yang hadir adalah 35 orang.

Dalam pembelajaran pada kelas ekperimen dengan menggunakan model pembelajaran Learning Cycle $7 E$ terlihat siswa siswa lebih semangat mengikuti pembelajaran karena dikaitkan dengan fenomena sehari-hari, siswa mengetahui aplikasi dari konsep yang ada, siswa menjadi lebih mengetahui contoh soal yang digunakan.

Pembelajaran banyak mendapat ketertundaan, karena banyaknya ketiadaan pembelajaran akibat kegiatan sekolah seperti Ujian Sekolah untuk kelas XII, Ulangan Tengah Semester, dan Ujian Nasional.

Kemudian setelah dilakukan pembelajaran diberikan posttest untuk mengetahui hasil belajar siswa. Pada kelas eksperimen diberikan posttest pada tanggal 21 April 2015 dengan jumlah siswa 35 orang dan kelas kontrol 17 April 2015 dengan jumlah siswa 32 orang. Untuk kelas ekeperimen didapatkan nilai rata-rat 71,543 dan kelas kontrol 60,625. Nilai rata-rata kedua kelas masih dibawah KKM (Kriteria Ketuntasan Minimal) yaitu 75, tetapi nilai rata posttest ini lebih tinggi dibandingkan dengan dengan nilai pretest, sehingga terdapat peningkatan.

Berdasarkan hasil uji hipotesis menggunakan uji-t, dapat disimpulkan bahwa terdapat pengaruh positif model pembelajaran Lerning Cycle $7 E$ terhadap hasil belajar siswa XI SMA pada pokok bahasan Fluida Dinamis dengan $\alpha=5 \%$, dimana nilai rata-rata kelas ekperimen yang menggunakan model pembelajaran Learning Cycle $7 E$ lebih tinggi daripada kelas kontrol yang menggunakan siklus belajar 5M dalam kurikulum 2013.

\section{PENUTUP}

Berdasarkan hasil penelitian dapat disimpulkan bahwa terdapat pengaruh model pembelajaran Learning Cycle 7E terhadap hasil belajar fisika siswa pada pokok bahasan Fluida Dinamis. Sehingga disimpulkan bahwa model pembelajaran Learning Cycle 7E dapat digunakan juga sebagai salah satu alternatif dalam pembelajaran kurikulum 2013.

\section{UCAPAN TERIMAKASIH}

Terimakasih kepada dosen pembimbing, guru fisika dan siswa XI MIPA SMAN 107 Jakarta dan pihak lain yang telah membantu penelitian ini. 


\section{REFERENSI}

Angel Guria. 2014. PISA 2012 Results in Focus. OECD.

Bandem Samudra, Gede, I wayan Suastra, dan Ketut Suma. 2014. "Permasalahan-permasalahan yang Dihadapi Siswa SMA di Kota Siangaraja dalam Mempelajari Fisika". e-Journal Program Pascasrjana Universitas Pendidikan Ganesha. Volume 4

Eeisenkraft, Arthur. 2003. "Expanding the 5E Model”. The Science Teacher. Volume 70, Nomor 6

Gonen, Selahattin. 2010. "A Physics Lesson Designed Acoording to 7E Model with The Help of Instructional Technology (Lesson Plan)". Turkish Online Journal of Distance Education (TOJDE). Volume 11, Nomor 1

Septian, Damar. 2011. "Pengaruh Model LC 7E dalam Pembelajaran Fisika terhadap Hasil Belajar Fisika Siswa MAN Rembang Tahun Ajaran 2010/2011”. Skripsi Sarjana pada UIN Sunan Kalijaga. Yogyakarta.

Spencer, Brenda H. dan Andrea M. Guillaume. 2006. "Integrating curriculum through the learning cycle: Content-based reading and vocabulary instruction". The Reading Teacher. Volume 60, Nomor 3

Sugiyono. 2011. Metode Penelitian Pendidikan. Bandung: Alfabeta

Trianto. 2014. Model Pembelajaran Terpadu. Jakarta: Bumi Aksara.

Yunita. 2014. Model-model Pembelajaran Kimia. Bandung: Insan Mandiri 
